\title{
Proses Ekstraksi Asam Asetat dari Distilat Asap Cair Tempurung Kelapa Menggunakan Pelarut Etil Asetat
}

\section{Acetic Acid Extraction from Coconut Shell Liquid Smoke Distillate Using Ethyl Acetate as Solvent}

\author{
Rory Faham Partogi Siregar, Erni Misran*, Iman Tri Cahyadi \\ Departemen Teknik Kimia, Fakultas Teknik, Universitas Sumatera Utara, \\ Jalan Almamater Kampus USU Medan 20155, Indonesia \\ *Email : erni2@usu.ac.id
}

\begin{abstract}
Abstrak
Tempurung kelapa merupakan biomasssa yang banyak ditemukan di Indonesia. Bahan ini berpotensi untuk digunakan sebagai bahan baku pembuatan asap cair. Asap cair adalah distilat asap yang merupakan campuran larutan dari dispersi asap hasil pirolisis biomassa. Salah satu senyawa yang cukup banyak dalam produk asap cair adalah asam asetat. Penelitian ini penting dilakukan untuk mengetahui pengaruh kombinasi proses distilasi dan ektraksi pada pemurnian asap cair untuk mendapatkan asam asetat. Kajian diarahkan untuk menganalisis pengaruh variasi rasio jumlah pelarut terhadap umpan asap cair $\left(2: 1,4: 1,6: 1\right.$, dan 8:1) dan temperatur ekstraksi $\left(30,50\right.$, dan $\left.70{ }^{\circ} \mathrm{C}\right)$ sehingga didapatkan yield, kandungan asam asetat, $\mathrm{pH}$, dan densitas ekstrak dengan variabel proses yang paling baik. Proses distilasi memiliki tujuan utama sebagai proses pemisahan komponen yang memiliki titik didih tinggi seperti tar. Proses ekstraksi memiliki tujuan utama sebagai proses lanjutan penyerapan asam asetat sehingga ekstrak memiliki kandungan asam asetat yang lebih tinggi. Pelarut yang digunakan dalam proses ekstraksi asam asetat ini adalah etil asetat. Analisis GC-MS digunakan untuk mengetahui komposisi asam asetat pada asap cair, distilat, dan ekstrak. Hasil GC-MS juga menunjukkan komposisi keseluruhan senyawa organik polar dalam ekstrak asap cair.
\end{abstract}

Kata kunci: asap cair, etil asetat, asam asetat, distilasi, ekstraksi

\begin{abstract}
Coconut shell is one of the most widely found biomass in Indonesia. It has potential to be utilized as raw material in producing liquid smoke. Liquid smoke is a distillate from pyrolysis of biomass. The distillate contains various compounds including acetic acid. This research is important to understand the effect of combined distillation and extraction on liquid smoke purificatian in obtaining acetic acid. The variation of solvent to feed ratio $(2: 1,4: 1,6: 1$, dan 8:1) and temperature of extraction (30, 50, dan $70{ }^{\circ} \mathrm{C}$ ) to obtain yield, acetic acid content, $\mathrm{pH}$, and density which is the best among those of possible variable given. The objective of distillation is to separate the components with high boiling points such as tar. The main purpose of extraction is acetic acid recovery in order to obtain higher content of acetic acid in extract. The solvent in the process of extracting acetic acid is ethyl acetate. GC-MS analysis was also performed on this research to show composition of acetic acid from liquid smoke, distillate, and extract, which are all the composition of polar organic are also shown.
\end{abstract}

Keywords: liquid smoke, ethyl acetate, acetic acid, distillation, extraction

\section{Pendahuluan}

Sebagai negara agraris yang terletak di daerah tropis, Indonesia memiliki limbah industri berupa biomassa. Limbah biomassa ini cukup melimpah dan sangat beraneka ragam yang berasal dari pertanian, pengolahan hutan, maupun tanaman yang tumbuh liar [14]. Indonesia merupakan salah satu negara penghasil kelapa yang utama di dunia. Rata-rata produksi kelapa Indonesia dari perkebunan rakyat pada periode 2000-2005 adalah sebesar 3.036.759 ton per tahun, sedangkan rata-rata produksi selama 
2006-2009 adalah 3.187.695 ton, atau meningkat sekitar 5 persen [2].

Asap cair adalah distilat asap yang merupakan campuran larutan dari dispersi asap hasil pirolisis kayu [5]. Kayu mengandung selulosa, hemiselulosa, dan lignin yang pada saat dibakar akan menghasilkan asap cair dengan banyak senyawa di dalamnya. Selain kayu, asap cair juga dapat dihasilkan dari bahan lain seperti tempurung kelapa, sabut kelapa, merang padi, bambu, dan sampah organik [15]. Asap cair saat ini mulai populer digunakan sebagai bahan pengawet pada berbagai produk pangan dan biopestisida dalam peningkatan produksi pertanian [1].

Pada penelitian ini ingin dikaji tentang upaya pengambilan asam asetat dari asap cair hasil pirolisis tempurung kelapa. Metode yang digunakan adalah distilasi dan ekstraksi. Asam asetat adalah senyawa alifatik asam karbonik yang paling banyak digunakan. Asam asetat juga sangat sering digunakan sebagai pelarut, diantaranya digunakan dalam pembuatan selulosa asetat dan pembuatan produk farmasi. Produksi dan pengambilan asam asetat dalam suatu proses tertentu memerlukan perhitungan dan pertimbangan secara ekonomis [11].

Distilasi merupakan salah satu cara pemurnian asam asetat dari asap cair yang memisahkan asam asetat dari senyawa lainnya berdasarkan perbedaan titik didihnya. Sedangkan pada ekstraksi, asam asetat dipisahkan dari asap cair dengan menggunakan pelarut. Pelarut dalam proses pengambilan asam asetat ini adalah senyawa etil asetat. Hal ini didasarkan pada teori bahwa etil asetat adalah salah satu ekstraktan yang cukup baik dalam pengambilan asam asetat yang dilihat dari koefisien distribusinya [6]. Dalam proses ekstraksi, rasio jumlah pelarut terhadap umpan dan suhu pada ekstraksi mempengaruhi seberapa banyak perolehan solut dan kandungan ekstrak yang didapat.

Sejauh ini belum ada kajian tentang pengambilan asam asetat dari asap cair yang memadukan dua metode pemisahan khususnya pada variabel rasio jumlah pelarut terhadap umpan pada proses ekstraksi. Penelitian ini penting dilakukan untuk mengetahui pengaruh variasi suhu pada distilasi dan variasi rasio jumlah pelarut terhadap umpan dan suhu ekstraksi sehingga didapatkan yield ekstrak, kandungan asam asetat, $\mathrm{pH}$, dan densitas dengan kondisi operasi yang paling baik. Komposisi asam asetat itu sendiri tergolong cukup banyak dalam asap cair hasil pirolisis tempurung kelapa yang dapat dipertimbangkan sebagai keuntungan dalam proses ekstraksi ini [3].

\section{Teori}

Pemanfaatan buah kelapa umumnya hanya daging buahnya saja untuk dijadikan kopra, minyak, dan santan untuk keperluan rumah tangga, sedangkan hasil samping lainnya seperti tempurung kelapa belum begitu banyak dimanfaatkan. Bobot tempurung mencapai $12 \%$ dari bobot buah kelapa. Dengan demikian, apabila secara rata-rata produksi buah kelapa per tahun adalah sebesar 5,6 juta ton, maka berarti terdapat sekitar 672 ribu ton tempurung yang dihasilkan [4].

Asap cair merupakan suatu hasil kondensasi atau pengembunan dari uap hasil pembakaran tidak langsung maupun langsung dari bahanbahan yang banyak mengandung karbon serta senyawa-senyawa lain. Bahan baku yang banyak digunakan adalah kayu, bongkol kelapa sawit, ampas hasil penggergajian kayu, dan lain-lain [10]. Untuk mendapatkan asap cair umumnya dilakukan pirolisis tipe cepat (fast pyrolysis) untuk menghasilkan yield produk cair yang lebih tinggi. Produk hasil pirolisis terbagi atas tiga yaitu padat berupa arang (char), cair (bio-oil), dan asap cair serta gas (syngas) [1].

Komposisi kimia utama asap cair tempurung kelapa adalah fenol 5,13\%; karbonil 13,28\%; dan asam 11,39\% [10]. Untuk meningkatkan komposisi asam astetat diperlukan proses lanjutan berupa distilasi asap cair seperti yang dicontohkan pada distilasi asap cair dari kulit durian, dimana proses ini dilakukan pada suhu $200{ }^{\circ} \mathrm{C}$ yang mampu meningkatkan komposisi asam asetat sampai 70,55\% [13].

Proses distilasi merupakan proses pemisahan suatu komponen dari suatu campuran dengan menggunakan dasar bahwa beberapa komponen dapat menguap lebih cepat daripada komponen yang lainnya. Ketika uap diproduksi dari campuran, uap tersebut lebih banyak berisi komponen-komponen yang bersifat lebih volatil, sehingga proses pemisahan komponen- 
komponen dari campuran dapat terjadi [10]. Ekstraksi merupakan salah satu proses pemisahan yang dilakukan untuk memindahkan dan menghilangkan komponen terlarut dalam suatu cairan ke cairan lainnya [15]. Proses ekstraksi cair-cair adalah salah satu alternatif yang dapat digunakan untuk pengambilan kembali asam karbosilat (dalam penelitian ini adalah asam asetat) pada industri.

\section{Metodologi Penelitian}

Bahan baku yang digunakan dalam penelitian ini adalah asap cair tempurung kelapa, aquadest, etil asetat $\left(\mathrm{C}_{2} \mathrm{H}_{5} \mathrm{OH}\right)$ teknis, natrium hidroksida $(\mathrm{NaOH}), \quad$ dan indikator phenolphthalein. Adapun peralatan utama yang digunakan untuk mengidentifikasi komponen kimia dari asap cair yang diperoleh adalah GCMS di LPKS Sumatera Utara dan Laboratorium Kimia Organik Universitas Gajah Mada.

\section{Prosedur Penelitian \\ Distilasi Asap Cair}

Bahan baku asap cair disiapkan sebanyak $300 \mathrm{ml}$ untuk setiap percobaan. Setelah itu, asap cair didistilasi selama 2 jam dengan suhu 105$120{ }^{\circ} \mathrm{C}$. Kondensat asap cair ditampung di wadah untuk selanjutnya dianalisis.

\section{Ekstraksi Asam Asetat dan Pemisahan Pelarut}

Sebanyak $50 \mathrm{ml}$ asap cair yang telah didistilasi disiapkan untuk proses ekstraksi. Umpan dimasukkan ke dalam labu ekstraksi, dan suhu pada hot plate diatur dengan variasi 30, 50, dan $70{ }^{\circ} \mathrm{C}$. Pelarut etil asetat dimasukkan ke dalam labu ekstraksi dengan variasi rasio pelarut terhadap umpan adalah $2: 1,4: 1,6: 1$, dan 8:1. Asap cair dan pelarut diaduk menggunakan mixer hot plate selama ekstraksi berlangsung.

Setelah 2 jam ekstraksi, ekstrak dan rafinat dipisahkan menggunakan corong pemisah. Etil asetat di-recovery menggunakan rotary evaporator dengan suhu $50{ }^{\circ} \mathrm{C}$ dan tekanan $-0,8$ bar. Ekstrak yang dihasilkan dicatat volumenya dan selanjutnya dianalisis.

\section{Metode Analisa}

Kedua yield distilat dan ekstrak dihitung menggunakan Persamaan 1.
Yield $=\frac{\text { Volume awal }}{\text { Volume yang diperoleh }} \times 100 \%$

Kandungan asam dianalisis dengan metode titrasi. Ekstrak yang diperoleh diambil sebanyak $1 \mathrm{~g}$ kemudian diencerkan dengan $10 \mathrm{~g}$ aquadest, lalu ditambah indikator phenolphthalein sebanyak 3 tetes. Setelah itu, sampel dititrasi dengan larutan $\mathrm{NaOH} 0,1 \mathrm{~N}$ sampai warna larutan berubah menjadi merah cerah. Jumlah volume $\mathrm{NaOH}$ dicatat dan digunakan untuk menghitung total kandungan asam yang dinyatakan sebagai asam asetat (Y) [7,10]. Kandungan asam asetat dihitung menggunakan Persamaan 2.

$$
\mathrm{Y}=\frac{\text { Volume } \mathrm{NaOH} \times \mathrm{N} \mathrm{NaOH} \times 60}{\text { Volume sampel }(\mathrm{ml} \times 1000)} \times 100 \%
$$

Nilai $\mathrm{pH}$ ekstrak diukur menggunakan $\mathrm{pH}$ meter ATC dengan menyiapkan $2 \mathrm{ml}$ ekstrak untuk setiap variabel yang digunakan. Langkah pertama sebelum menentukan $\mathrm{pH}$ adalah membuat kalibrasi standar dengan bantuan dari agent buffer $\mathrm{pH}$ 4,0 dan 7,0. Pengukuran $\mathrm{pH}$ sampel dilakukan dengan menempatkan meteran elektroda $\mathrm{pH}$ ke dalam sampel dan nomor digital masing-masing sampel dicatat.

Densitas diukur dengan menggunakan piknometer, dengan menimbang air sebagai kalibrasi pertama. Densitas dihitung menggunakan Persamaan 3.

Berat piknometer dan sampel $(\mathrm{g})$ - Berat piknometer kosong $(\mathrm{g})$ Berat piknometer dan air (g) - Berat piknometer kosong (g)

Analisis GC-MS (QP2010S SHIMADZU JAPAN) juga dilakukan pada penelitian ini untuk menunjukkan semua komposisi senyawa organik polar termasuk asam asetat dari asap cair, distilat, dan ekstrak.

\section{Hasil}

\section{Analisis Yield Distilat Asap Cair}

Proses distilasi asap cair umumnya dilakukan untuk fraksinasi komponen asap cair berdasarkan perbedaan titik didihnya. Pada penelitian ini hasil fraksinasi distilat yang diperoleh hampir sama dengan fraksinasi pada penelitian sebelumnya dimana yield terbesar berada pada suhu $105{ }^{\circ} \mathrm{C}$ sampai $120^{\circ} \mathrm{C}$. Tidak semua komponen dapat terdistilasi yaitu 
komponen berupa tar dan zat kimia yang titik didihnya di atas suhu pemanasan maksimal distilasi. Tar kayu yang dihasilkan dari pirolisis seperti dicontohkan pada kayu pinus umumnya larut pada senyawa organik namun kelarutannya kecil dalam air [4]. Untuk itu, fungsi utama dari distilasi ini adalah pemisahan tar yang merupakan zat berbahaya dan juga sangat larut dengan pelarut etil asetat pada proses ekstraksi selanjutnya. Yield distilat yang dihasilkan pada berbagai suhu dapat dilihat pada Gambar 1 .

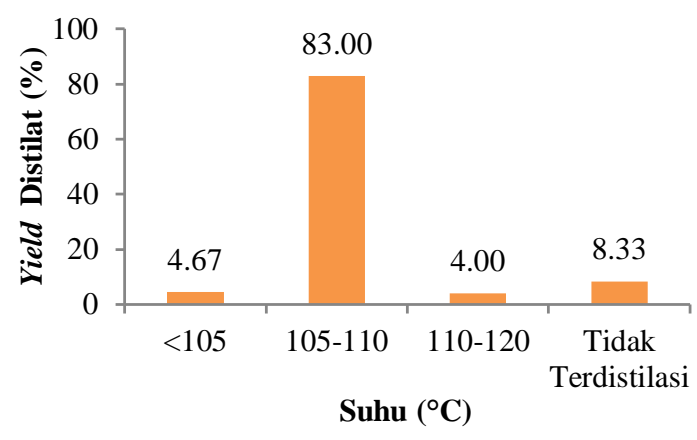

Gambar 1. Yield Distilat Berdasarkan Fraksinasi Berbagai Suhu

Pada suhu <105 ;105-110; 110-120 ${ }^{\circ} \mathrm{C}$ proses distilasi menunjukkan yield distilat sebesar 4,67 \%; 83,00\%; 4,00\%, serta bagian tidak terdistilasi sebesar $8,33 \%$. Peneliti sebelumnya mendistilasi asap cair dari tempurung dan serabut kelapa dimana pada suhu $100{ }^{\circ} \mathrm{C}$ kuantitasnya sebesar $15,9-45,5 \%$ dan pada suhu 100-125 ${ }^{\circ} \mathrm{C}$ sebesar 7,5-14,7 \% dimana keduanya merupakan fraksi yang terbesar dibandingkan fraksi pada suhu lainnya [8]. Peneliti lainnya melakukan redistilasi asap cair dari tempurung kelapa hibrida dimana yield tertinggi dihasilkan pada suhu $100-110{ }^{\circ} \mathrm{C}$ yaitu sebesar 85,70\% [4].

Besarnya yield pada rentang suhu 105$120{ }^{\circ} \mathrm{C}$ disebabkan komponen senyawa pada distilat berupa asam asetat dan air yang merupakan senyawa yang banyak dalam komposisi asap cair yang memiliki titik didih dalam rentang suhu distilasi tersebut. Pemilihan rentang suhu $105-120{ }^{\circ} \mathrm{C}$ didasarkan bahwa pada suhu tersebut yield yang didapatkan paling besar namun kandungan asam asetat yang diperoleh paling kecil [4,8]. Untuk itu pada fraksinasi distilat perlu dilakukan proses lanjutan berupa ekstraksi.

\section{Analisis Yield Ekstrak Asap Cair}

Proses ekstraksi asap cair umumnya dilakukan untuk mendapatkan komponen yang diinginkan dalam hal ini adalah asam asetat. Hasil ekstrak yang dihasilkan pada berbagai suhu dan jumlah pelarut dapat dilihat pada Gambar 2.

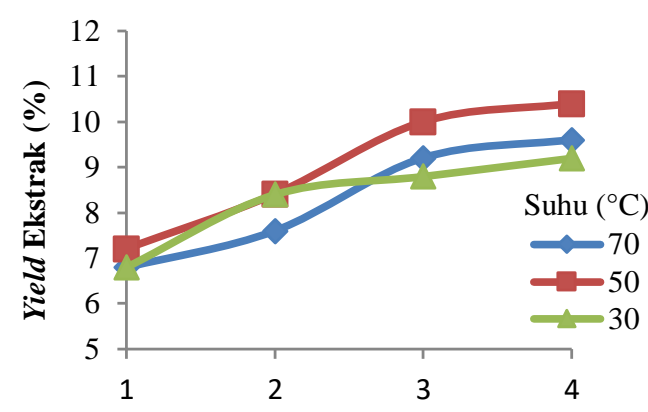

Rasio Pelarut : Umpan

Gambar 2. Yield Ekstrak Berdasarkan Variasi Suhu dan Rasio Pelarut terhadap Umpan

Pada variasi rasio pelarut terhadap umpan 2:1, 4:1, 6:1, dan 8:1 dengan suhu $70{ }^{\circ} \mathrm{C}$ didapatkan yield berturut-turut 6,$8 ; 7,6 ; 9,2$; dan $9,6 \%$, sedangkan pada suhu $50{ }^{\circ} \mathrm{C}$ pada variasi rasio pelarut terhadap umpan $2: 1 ; 4: 1 ; 6: 1$, dan $8: 1$ didapatkan yield berturut-turut 7,$2 ; 8,4 ; 10$; dan $10,4 \%$, dan pada suhu $30{ }^{\circ} \mathrm{C}$ pada variasi rasio pelarut terhadap umpan yaitu $2: 1 ; 4: 1 ; 6: 1$, dan $8: 1$ didapatkan yield berturut-turut 6,$8 ; 8,4$; 8,8; dan 9,2\%.

Pada Gambar 2 dapat dilihat bahwa kenaikan yield dipengaruhi oleh penambahan jumlah pelarut. Variasi suhu juga mempengaruhi yield ekstrak asap cair. Namun di beberapa titik pada suhu $70{ }^{\circ} \mathrm{C}$, yield yang diperoleh berada di antara suhu $30^{\circ} \mathrm{C}$ dan $50{ }^{\circ} \mathrm{C}$.

Berdasarkan pengamatan yang dilakukan, pada suhu $70{ }^{\circ} \mathrm{C}$ terdapat etil asetat yang mulai menguap dan kemudian berkurang walaupun sudah dilakukan refluks dengan air yang memiliki suhu kamar. Adanya pengurangan jumlah volume pelarut pada variasi suhu ini dapat berakibat langsung terhadap yield ekstrak. Dalam penelitian ini, yield terbanyak dihasilkan pada suhu $50{ }^{\circ} \mathrm{C}$ dan rasio pelarut terhadap umpan 8:1 yakni sebesar 10,4\%.

Peneliti sebelumnya mendapatkan volume terekstrak sebesar 3,248\% dengan pemakaian rasio pelarut terhadap umpan yaitu 1:1 dan waktu 10 sampai 30 menit. Namun dalam penelitian 
tersebut tidak dilakukan penguapan pelarut secara sempurna [15]. Hasil yang didapat menunjukkan kenaikan suhu dan penambahan pelarut mempengaruhi penyerapan ekstrak karena yield yang didapat sudah lebih banyak daripada hasil peneliti sebelumnya.

\section{Analisis Kandungan Asam Asetat}

Kandungan asam asetat pada bahan baku asap cair tempurung kelapa dalam penelitian ini adalah sebesar $8,80 \%$. Nilai kandungan asam asetat ini lebih rendah dari data peneliti sebelumnya, dimana asap cair yang diperoleh sebesar $15,59 \%$ pada suhu pirolisis $300{ }^{\circ} \mathrm{C}$ [15]. Selain itu, kandungan asam asetat pada bahan distilat asap cair tempurung kelapa dalam penelitian ini adalah sebesar $6,80 \%$. Dua peneliti sebelumnya dalam penelitiannya mengenai distilasi asap cair tempurung kelapa mendapatkan kandungan asam berkisar 4,94\% [4] dan 8,08 - 18,92 \% [15] pada suhu fraksinasi di $100-125^{\circ} \mathrm{C}$.

Hasil kandungan asam asetat yang diperoleh pada ekstrak dan rafinat ditunjukkan pada Gambar 3 dan 4.

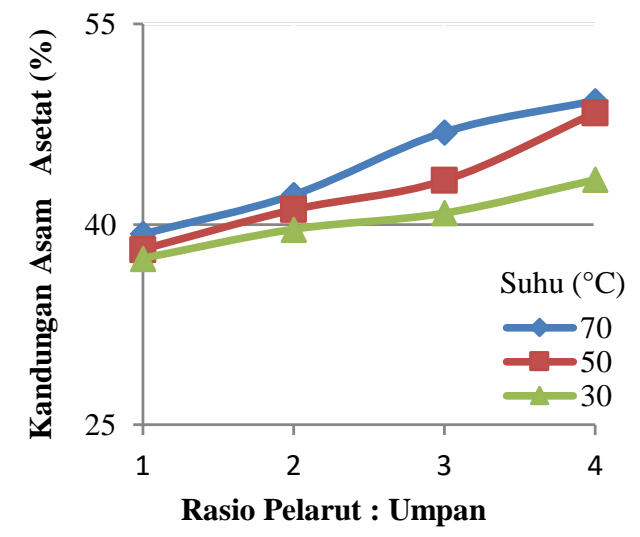

Gambar 3. Kandungan Asam Asetat Berdasarkan Variasi Suhu dan Rasio Pelarut : Umpan pada Fasa Ekstrak

Pada variasi rasio pelarut terhadap umpan dengan suhu $70{ }^{\circ} \mathrm{C}$ yaitu $2: 1,4: 1,6: 1$, dan $8: 1$ didapatkan kandungan asam asetat berturut-turut 39,29; 42,21; 46,90; dan 49,26\%, sedangkan pada variasi rasio pelarut terhadap umpan pada suhu $50{ }^{\circ} \mathrm{C}$ yaitu 2:1, 4:1, 6:1, dan 8:1 didapatkan kandungan asam asetat berturut-turut 38,14; 41,$11 ; 43,30$; dan 48,35\%; dan pada variasi rasio pelarut terhadap umpan pada suhu $30{ }^{\circ} \mathrm{C}$ yaitu $2: 1,4: 1,6: 1$, dan 8:1 didapatkan kandungan asam asetat berturut-turut 37,$45 ; 39,64 ; 40,85$; dan $43,36 \%$.

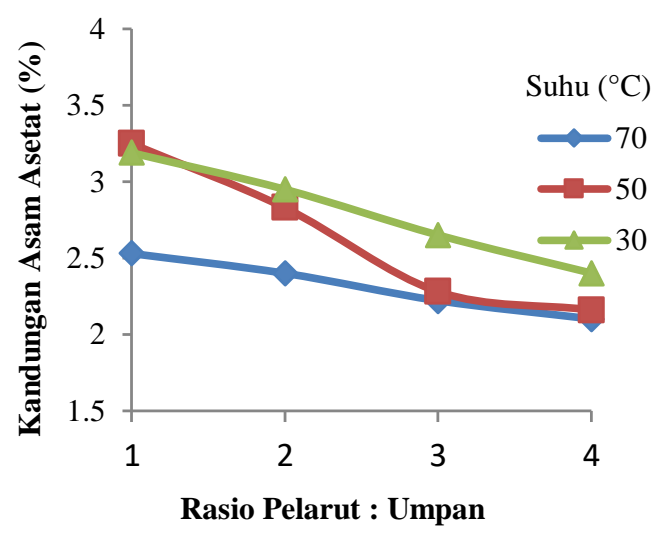

Gambar 4. Kandungan Asam Asetat Berdasarkan Variasi Suhu dan Rasio Pelarut : Umpan pada Fasa Rafinat

Dalam penelitian ini, kandungan asam asetat yang tertinggi dihasilkan pada suhu $70{ }^{\circ} \mathrm{C}$ dengan rasio pelarut terhadap umpan 8:1 sebesar $49,26 \%$. Peneliti sebelumnya memperoleh kandungan asam asetat sebesar 6,982\% dengan pemakaian rasio pelarut terhadap umpan yaitu 1:1 dan waktu 10 sampai 30 menit [15]. Namun dalam penelitian tersebut tidak dilakukan penguapan pelarut secara sempurna. Kemiripan kandungan asam pada ekstrak menyamai hasil distilat asap cair peneliti sebelumnya yang dilakukan pada variasi suhu tertinggi $125-150{ }^{\circ} \mathrm{C}$ sebesar 43,96 - 44,24\% [4], dimana pada distilat tersebut kandungan air diperoleh sangat sedikit. Besarnya kandungan asam asetat yang diperoleh pada penelitian ini menunjukkan bahwa etil asetat cukup baik dalam mengekstraksi asam asetat.

Selain itu, data kandungan asam asetat yang diperoleh pada fasa rafinat dapat membuktikan kemampuan etil asetat dalam mengekstraksi asam asetat seperti yang ditampilkan pada Gambar 4. Pada variasi rasio pelarut terhadap umpan pada suhu $70{ }^{\circ} \mathrm{C}$ yaitu yaitu $2: 1,4: 1,6: 1$, dan 8:1 diperoleh kandungan asam asetat berturut-turut 2,$53 ; 2,40 ; 2,22$; dan $2,10 \%$; sedangkan pada variasi rasio pelarut terhadap umpan pada suhu $50{ }^{\circ} \mathrm{C}$ yaitu yaitu $2: 1,4: 1,6: 1$, dan 8:1 diperoleh kandungan asam asetat 
berturut-turut 3,$25 ; 2,83 ; 2,28$; dan $2,16 \%$ dan pada variasi rasio pelarut terhadap umpan pada suhu $30{ }^{\circ} \mathrm{C}$ yaitu yaitu $2: 1,4: 1,6: 1$, dan $8: 1$ diperoleh kandungan asam asetat berturut-turut 3,$19 ; 2,95 ; 2,65 ;$ dan $2,40 \%$. Peneliti sebelumnya mendapatkan kandungan asam asetat pada crude atau rafinat sebesar 11,05\% dengan pemakaian rasio pelarut terhadap umpan yaitu 1:1 dan waktu 10 sampai 30 menit [15]. Dalam penelitian ini \% asam asetat terkecil dihasilkan pada suhu $70{ }^{\circ} \mathrm{C}$ dengan rasio pelarut terhadap umpan 8:1 sebesar 2,10 \% yang menandakan pada variasi percobaan tersebut merupakan penyerapan asam asetat yang terbaik.

\section{Analisis Nilai pH}

Nilai $\mathrm{pH}$ merupakan salah satu parameter kualitas ekstrak yang dihasilkan. Pengukuran nilai $\mathrm{pH}$ dalam ekstrak asap cair yang dihasilkan bertujuan untuk mengetahui seberapa besar terserapnya asam asetat dalam ekstrak dari sifat keasamannya. Hasil pengukuran $\mathrm{pH}$ pada ekstrak asap cair berbagai variasi suhu dan rasio pelarut terhadap umpan dapat dilihat pada Gambar 5.

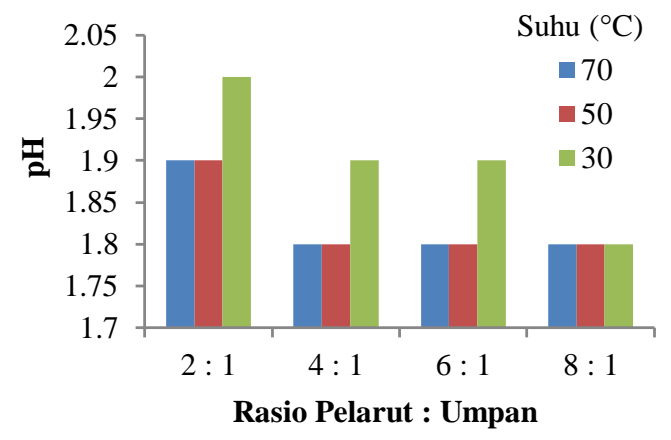

Gambar 5. Nilai pH Ekstrak Asap Cair Berbagai Variasi Suhu dan Rasio Pelarut Terhadap Umpan

Nilai $\mathrm{pH}$ pada penelitian ini berkisar 1,8 sampai 2, dimana kandungan asam tertinggi memiliki pH 1,8. Peneliti sebelumnya mendapatkan nilai $\mathrm{pH}$ yang nilainya lebih tinggi dengan nilai $\mathrm{pH}$ sebesar 3,113. Namun peneliti sebelumnya belum melakukan penguapan pelarut secara sempurna, dimana masih ada sisa pelarut yang memiliki $\mathrm{pH}$ lebih besar dari asam asetat [15]. Kemiripan ekstrak juga hampir menyamai hasil distilat asap cair yang dilakukan pada variasi suhu tertinggi $125-150{ }^{\circ} \mathrm{C}$ yang dilakukan dengan $\mathrm{pH}$ sebesar 1,76 [4]. Berdasarkan teori bahwa $\mathrm{pH}$ asam asetat sebesar
1 Molaritas bernilai 2,5 [9]. Hal ini menunjukkan bahwa asam asetat pada ekstrak memiliki konsentrasi lebih dari 1 Molaritas.

\section{Analisis Densitas}

Berat jenis dari ekstrak perlu diketahui untuk mengetahui baku mutu pada asam asetat. Densitas juga menunjukkan komponen yang terkandung di dalam asap cair itu sendiri. Hasil densitas yang diperoleh dalam penelitian ini dapat dilihat pada Gambar 6.

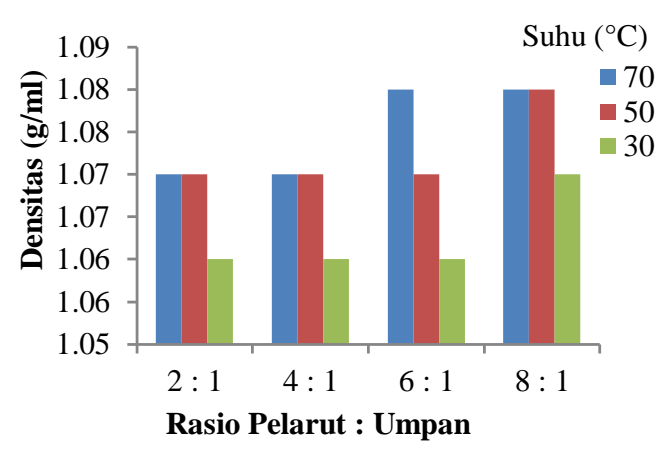

Gambar 6. Perbandingan Nilai pH Ekstrak Asap Cair Terhadap Kandungan Asam Asetat pada Ekstrak

Dari data di atas dapat dilihat maka nilai densitas semakin tinggi. Nilai densitas pada penelitian ini berkisar 1,06 sampai 1,08 gr/ml, dimana densitas tertinggi memiliki densitas 1,08 gr/ml. Peneliti sebelumnya mendapatkan densitas ekstrak sebesar 0,9385 gr/ml. Namun peneliti sebelumnya belum melakukan penguapan pelarut secara sempurna, dimana masih ada sisa pelarut yang memiliki densitas lebih rendah dari asam asetat [15]. Kemiripan ekstrak menyamai hasil distilat asap cair yang dilakukan pada variasi suhu tertinggi $125-150{ }^{\circ} \mathrm{C}$ yang dilakukan dengan densitas sebesar 1,12 $\mathrm{gr} / \mathrm{ml}$ [4]. Berdasarkan teori bahwa densitas asam asetat sebesar sebesar 1,05 [15]. Perbedaan densitas ini disebabkan oleh kemurnian ekstrak yang tidak mencapai $100 \%$ dimana terdapat komponen senyawa lain seperti fenol dan karbonil yang memiliki densitas berbeda.

\section{Analisis GC-MS}

Analisis GC-MS (Gas Chromatography Mass Spectrometry) bertujuan untuk mengidentifikasi gugus fungsi dari struktur kimia dalam suatu senyawa. Kromatogram hasil 
GC-MS ditunjukkan pada Gambar 7 dan komposisi asap cair tempurung ditunjukkan pada

Tabel 1.

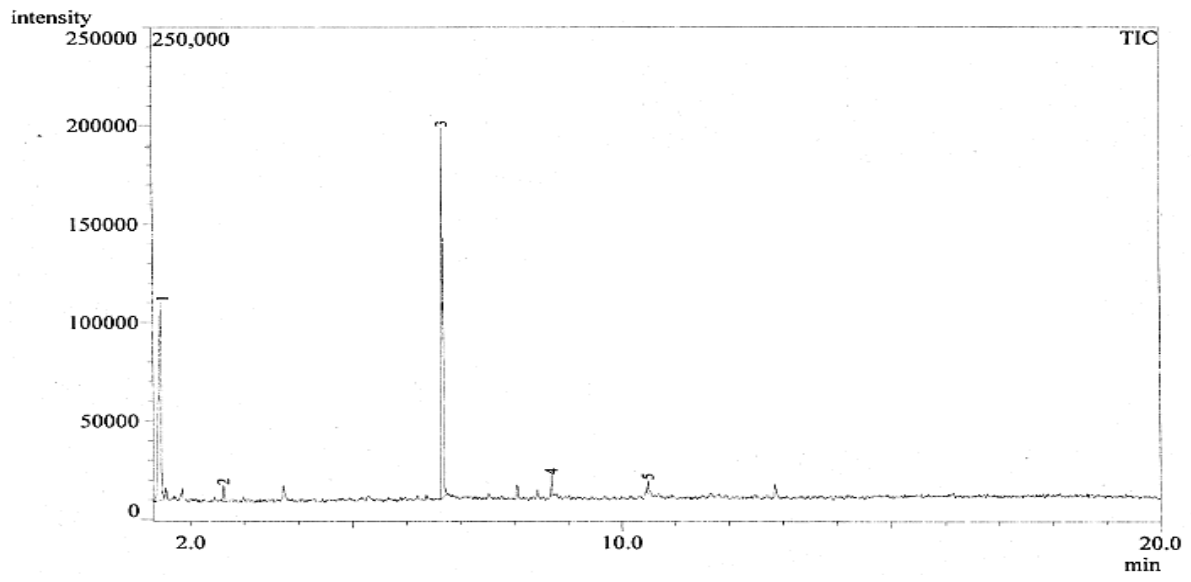

Gambar 7. Kromatogam GC-MS Asap Cair Tempurung Kelapa

Tabel 1. Komposisi Asap Cair Tempurung Kelapa

\begin{tabular}{|r|r|r|l|}
\hline Peak & R.time & $\%$ Area & \multicolumn{1}{|c|}{ Nama } \\
\hline 1 & 1,441 & 46,40 & $\begin{array}{l}\text { Asam asetat (CAS), } \\
\text { asam etilat, asam } \\
\text { vinegar, asam } \\
\text { etanoat, asam } \\
\text { asetat glasial }\end{array}$ \\
\hline 2 & 3,148 & 2,06 & $\begin{array}{l}\text { Butana, 2-nitro- } \\
\text { (CAS) 2- } \\
\text { nitrobutana }\end{array}$ \\
\hline 3 & 3,585 & 47,07 & Fenol (CAS) izal \\
\hline 4 & 3,915 & 2,54 & $\begin{array}{l}\text { Fenol, 2-metoksi- } \\
\text { (CAS) guaikol }\end{array}$ \\
\hline 5 & 5,876 & 1,94 & $\begin{array}{l}\text { 1,2-benzedinol (cas) } \\
\text { pirokatekol }\end{array}$ \\
\hline & Total & 100,00 & \\
\hline
\end{tabular}

Hasil GC-MS menunjukkan bahwa komponen asam asetat pada asap cair bahan baku sebesar $46,40 \%$ dimana hasil mendekati hasil GC-MS peneliti terdahulu yaitu sebesar 40,20\% yang dihasilkan pada suhu $400{ }^{\circ} \mathrm{C}$ [13]. Komponen terbesar dalam asap cair tempurung kelapa terdiri atas asam asetat dan fenol. Besarnya komposisi asam asetat disebabkan tingginya kandungan komposisi selulosa dan hemiselulosa pada bahan baku yaitu tempurung kelapa sedangkan komposisi fenol dipengaruhi oleh kandungan lignin bahan baku [4].

Kromatogram hasil GC-MS ditunjukan pada Gambar 8 dan komposisi distilat asap cair yang dihasilkan pada suhu 105-120 ${ }^{\circ} \mathrm{C}$ ditunjukkan pada Tabel 2. Hasil GC-MS menunjukkan bahwa komponen asam asetat sebesar $41,80 \%$ dimana hasil mendekati komposisi asap cair tempurung kelapa bahan baku.

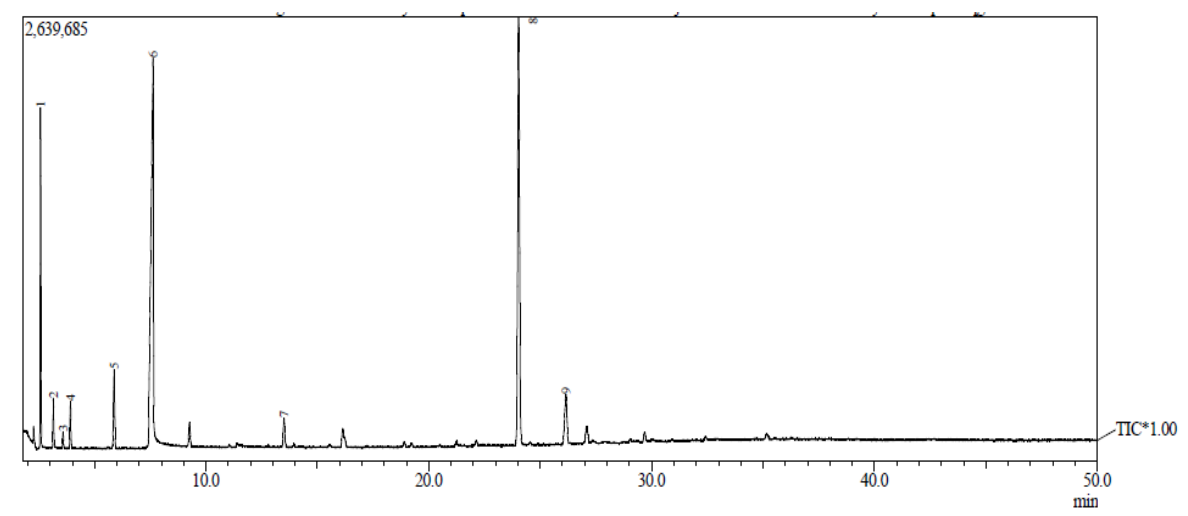

Gambar 8. Kromatogam GC-MS Distilat Asap Cair pada Suhu Distilasi 105-120 ${ }^{\circ} \mathrm{C}$ 
Tabel 2. Komposisi Distilat Asap Cair

\begin{tabular}{|c|c|r|l|}
\hline Peak & R.time & \% Area & \multicolumn{1}{|c|}{ Nama } \\
\hline 1 & 2,525 & 10,58 & $\begin{array}{l}\text { Metilamina, } \\
\text { trideuetana, } \\
\text { florometana, etilen } \\
\text { glikol }\end{array}$ \\
\hline 2 & 3,148 & 1,73 & $\begin{array}{l}\text { Alkohol; (Etil } \\
\text { alkohol) }\end{array}$ \\
\hline 3 & 3,585 & 0,60 & $\begin{array}{l}\text { Keton; (aseton. } \\
\text { propanon. dimetil } \\
\text { keton) }\end{array}$ \\
\hline 4 & 3,915 & 1,75 & $\begin{array}{l}\text { Asam asetat, metil } \\
\text { ester }\end{array}$ \\
\hline 5 & 5,876 & 3,97 & $\begin{array}{l}\text { Etil asetat, asam } \\
\text { asetat }\end{array}$ \\
\hline 6 & 7,622 & 41,80 & Asam asetat \\
\hline 7 & 13,501 & 1,69 & $\begin{array}{l}\text { Keton; (hidroksi-2- } \\
\text { butanon), Asam } \\
\text { propanoat, } \\
\text { Anhidrat;(metilaset } \\
\text { at anhidrat. } \\
\text { propanoat anhidrat) }\end{array}$ \\
\hline 8 & 24,026 & 34,09 & $\begin{array}{l}\text { Fenol; (benzenol. } \\
\text { monofenol) }\end{array}$ \\
\hline 9 & 26,156 & 3,80 & $\begin{array}{l}\text { Fenol; } \\
\text { (metoksifenol. } \\
\text { guasol) }\end{array}$ \\
\hline & Total & 100,00 & and \\
\hline
\end{tabular}

Komponen terbesar dalam distilat asap cair terdiri atas asam asetat dan fenol. Adapun penurunan komposisi pada asam asetat dan fenol menunjukkan pada saat pemisahan menggunakan proses distilasi sisa komponen yang tidak terpisahkan mengandung komponen asam asetat dan fenol.

Kromatogram hasil GC-MS ditunjukan pada Gambar 9 dan komposisi ekstrak asap cair ditunjukkan pada Tabel 3. Hasil GC-MS

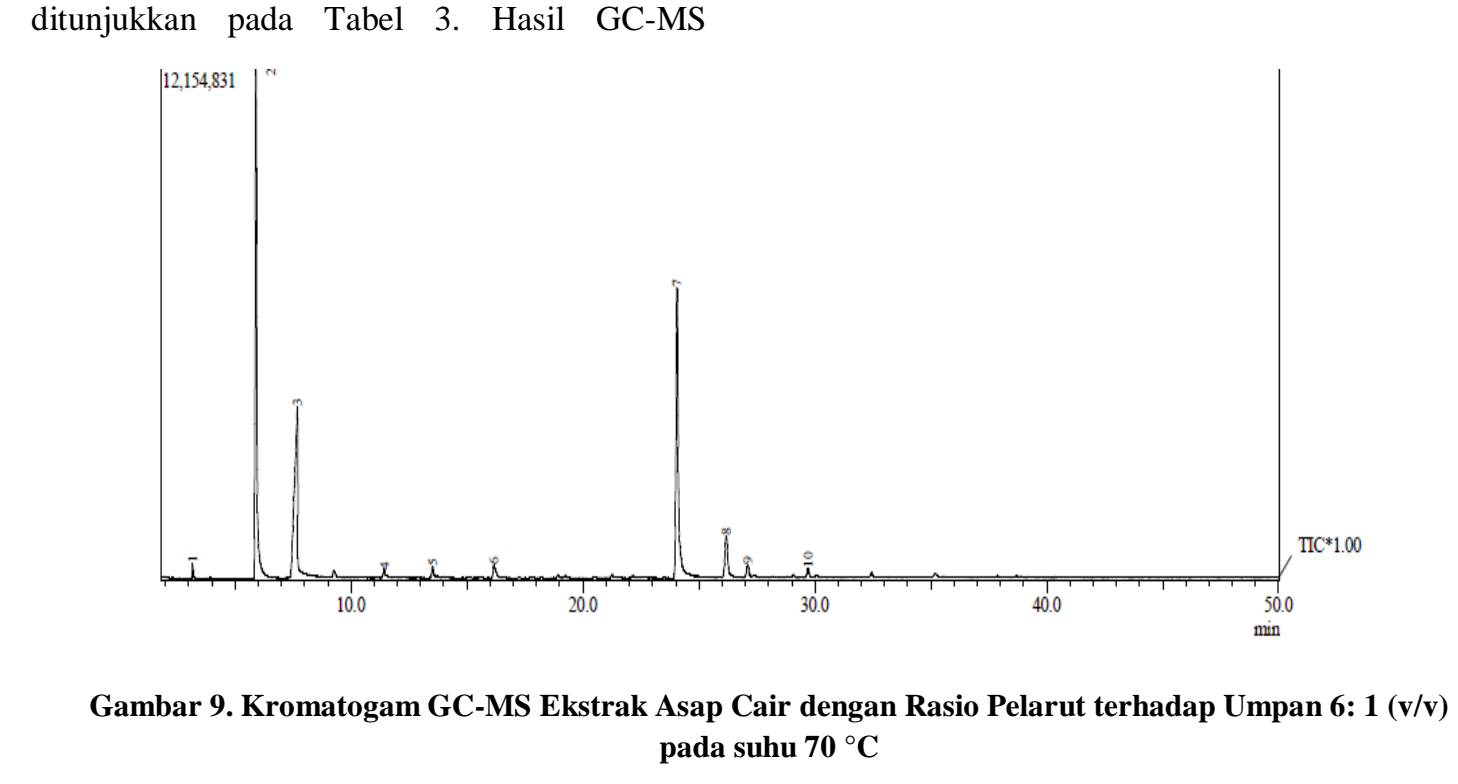

Gambar 9. Kromatogam GC-MS Ekstrak Asap Cair dengan Rasio Pelarut terhadap Umpan 6: 1 (v/v) pada suhu $70{ }^{\circ} \mathrm{C}$ menunjukkan komponen asam asetat sebesar $24,00 \%$ dan $36,80 \%$ campuran etil asetat asam asetat. Pembacaan hasil GC-MS pada peak 2 menunjukkan adanya bacaan terjemahan gugus EtOAC yang dapat diartikan sebagai etil asetat dan OAC sebagai gugus asam asetat. Komponen asam asetat berkurang dari distilat asap cair menunjukkan bahwa sisa pelarut dapat menurunkan komposisi senyawa pada ekstrak. Adanya komponen etil asetat sisa menandakan perlunya penambahan waktu pada proses penguapan untuk mendapatkan komposisi asam asetat yang lebih besar. Komponen berkurang secara signifikan yaitu yaitu methylamine, trideuetana, florometana sebesar 10,58\%. Senyawa metil amina, trideuetana, dan florometana memiliki titik didih di bawah $0{ }^{\circ} \mathrm{C}$ yang kemungkinan telah menguap pada proses ekstraksi yang mengunakan suhu di atas suhu kamar. Etilen glikol juga tidak ada dalam ekstrak yang menandakan pelarut tidak menyerap etilen glikol.

Komposisi yang terbaca pada instrumen GC-MS kebanyakan merupakan senyawa organik polar, sehingga komponen air tidak terdeteksi dalam ekstrak asap cair. Komponen air yang cukup banyak dalam asap cair dapat menurunkan kandungan senyawa organik dalam ekstrak asap cair. Untuk itu perlu dilakukan analisa kuantitatif sebagai analisa lanjutan pendukung baik kandungan dan perolehan senyawa organik terkhusus senyawa asam asetat. 
Tabel 3. Komposisi Ekstrak Asap Cair

\begin{tabular}{|c|r|r|l|}
\hline Peak & R.time & \multicolumn{1}{|c|}{ \% Area } & \multicolumn{1}{|c|}{ Nama } \\
\hline 1 & 3,161 & 0,67 & Etanol \\
\hline 2 & 5,897 & 36,83 & Etil asetat; asam asetat \\
\hline 3 & 7,688 & 24,00 & Asam asetat \\
\hline 4 & 11,437 & 0,38 & Asam propanoat \\
\hline 5 & 13,512 & 0,79 & $\begin{array}{l}\text { Keton; (hidroksi-2- } \\
\text { butanon); Asam } \\
\text { propanoat }\end{array}$ \\
\hline 6 & 16,164 & 1,27 & $\begin{array}{l}\text { Furfural. } \\
\text { furankarboksaldehida }\end{array}$ \\
\hline 7 & 24,504 & 29,65 & $\begin{array}{l}\text { Fenol; (benzenol. } \\
\text { monofenol) }\end{array}$ \\
\hline 8 & 26,187 & 4,67 & $\begin{array}{l}\text { Fenol; (metoksifenol. } \\
\text { guasol) }\end{array}$ \\
\hline 9 & 27,107 & 1,09 & $\begin{array}{l}\text { Fenol; (metoksifenol. } \\
\text { kresol) }\end{array}$ \\
\hline 10 & 29,702 & 0,67 & $\begin{array}{l}\text { Benzena. Fenol; } \\
\text { (metoksifenol. kresol) }\end{array}$ \\
\hline & Total & 100,00 & \\
\hline
\end{tabular}

\section{Kesimpulan}

Data dari rasio pelarut terhadap umpan dan suhu yang diperoleh dimana paling banyak peningkatan variabel ini mempengaruhi ekstrak yang diperoleh.. Data menunjukkan senyawa asap cair, kadar asam asetat, $\mathrm{pH}$ dan kepadatan dari hasil ekstraksi masih jauh dari aplikasi makanan. Studi tertentu tentang optimasi pelarut dan suhu juga modifikasi proses seperti; lebih banyak tahap recovery pelarut yang dipelajari untuk melengkapi efektivitas ekstraksi asam asetat dari asap cair. Analisis lebih lanjut untuk menentukan kadar asam asetat juga direkomendasikan seperti analisis UV-VIS untuk memberikan data yang lebih tepat daripada titrasi asam asetat.

\section{Daftar Pustaka}

[1] B. Kilinc and S. Cakh, Turkish Journal of Fisheries and Aquatic Science, 12, (2012) 285-290.

[2] Dinas Perkebunan Kabupaten Lampung Barat, Road Map Pengembangan Komoditas Kelapa Kabupaten Lampung Barat, Penerbit Dinas Perkebunan Kabupaten Lampung Barat, 2007, p. 1-10.
[3] E. Himawati, Bachelor Thesis, Fakultas Pertanian, Universitas Sebelas Maret, Surakarta, 2010.

[4] E. Noor, C. Luditama, and G. Pari, Prosiding Konferensi Nasional Kelapa VIII, Jambi, Indonesia, 2014.

[5] Fachraniah, F. Zahra, and Z. Rahmi, Jurnal Sains dan Teknologi Reaksi, 2009, 7.1 .

[6] F.H. Garner and S.R.M. Ellis, Chemical Engineering Science, 2, (1953) 282-286.

[7] J. Z. Lombok, B.Setiaji, W. Trisunaryanti, and K. Wijaya, Asian Journal of Science and Technology, 5, (2014) 320-325.

[8] Material Safety Data Sheet, Genuine Pine Tar 850, www.pinetarworld.com, diakses pada 11 November 2015.

[9] Merck Material Safety Data Sheet, Acetic Acid, www.merck.com, 2011, diakses pada 11 November 2015.

[10] N. Alexandra, C.M. Oliveira, Brian H. Himelbloom, Mary Beth Leigh \& Charles A. Crapo. 2013. Food Science \& Nutrition. P. 102-115.

[11] QVF ENGINEERING GMBH, Recovery Of Acetic Acid By Means Of LiquidLiquid Extraction, www.dedietrich.com, diakses pada 11 November 2015.

[12] S. Kadir, P. Darmadji, C. Hidayat, and Supriyadi, Jurnal Agritech, 30, (2010) 5767.

[13] S. Kadir, P. Darmadji, C. Hidayat, and Supriyadi, Jurnal Agroland, 21 (2014) 714.

[14] S. Sunarsih, Y. Pratiwi, and Y. Sunarto, Prosiding Seminar Nasional Aplikasi Sains \& Teknologi (SNAST) Periode III, Yogyakarta, Indonesia, 2012.

[15] Sutin, Bachelor Thesis, Fakultas Teknologi Pertanian, Institut Pertanian Bogor, Bogor, 2008. 